ЗАТВЕРАЖЕНО

Наказ Міністерства охорони

зАОров'я України

30 груАня 2015 року № 916

\title{
Уніфікований клінічний протокол екстреної, первинної, вторинної (спеціалізованої) та третинної (високоспеціалізованої) медичної допомоги Медикаментозна алергія, включаючи анафілаксію (Вибрані положення)
}

\begin{tabular}{|c|c|}
\hline \multicolumn{2}{|c|}{ ПЕРЕАІК СКОРОЧЕНЬ, ЩО ВИКОРИСТОВУЮТЬСЯ У ПРОТОКОА } \\
\hline $\mathrm{A} \Gamma$ & антиген \\
\hline $\mathrm{A} \sqcap Ф$ & ангіотензинперетворюючий фермент \\
\hline AT & артеріальний тиск \\
\hline ІІГВB & імуноглобуліни А^я внутрішньовенного ввеАення \\
\hline $\mathrm{BI} \wedge$ & вірус імунодефіциту Аюдини \\
\hline ГКС & гАюкокортикостероїАи \\
\hline ГOTAP & гостра токсико-алергічна реакція \\
\hline EГАС & езофагогастродуоденоскопія \\
\hline EKГ & електрокардіограма / електрокардіографія \\
\hline 303 & заклади охорони зАоров'я \\
\hline КМП & клінічний маршрут пацієнта \\
\hline$\wedge 3$ & ^ікарські засоби \\
\hline$\wedge П \mathrm{M} \triangle$ & ^ока^ьні протоколи меАичної Аопомоги \\
\hline MA & медикаментозна алергія \\
\hline MO3 & Міністерство охорони зАоров'я \\
\hline МПТ & меАикаментозний провокаційний тест \\
\hline HAMH & Національна академія медичних наук \\
\hline НППЗ & $\begin{array}{l}\text { нестероїАні протизапальні та протиревматичні } \\
\text { засоби }\end{array}$ \\
\hline СРБ & С-реактивний білок \\
\hline УЗ3А & ультразвукове АосліАження \\
\hline УКПМА & $\begin{array}{l}\text { Уніфікований кАінічний протокол меАичної } \\
\text { АОпомоги }\end{array}$ \\
\hline ЦІК & циркулюючі імунні комплекси \\
\hline ЦНС & центральна нервова система \\
\hline DRESS & $\begin{array}{l}\text { Drug-Related Eosinophilia and Systemic Simptoms } \\
\text { syndrom (синдром медикаментозних реакцій } \\
\text { з еозинофілією і системними симптомами) }\end{array}$ \\
\hline $\lg$ & імуноглобулін \\
\hline RW & реакція Вассермана \\
\hline
\end{tabular}

\section{II. Загальна частина}

МеАикаментозна алергія - патологічна реакція на лікарські засоби, в основі якої лежать імунологічні механізми.

На сьогоАні в Україні віАсутня спеціальна система реєстрації саме меАикаментозної алергії (МА), віАповіАно - віАсутня точна інформація щоАо кількості реакцій гіперчутливості АО ^3, а також типів реакцій та їх насліАків. Крім того, віАсутні Аані про ефектив- ність їх ^ікування як на госпітальному, так і на амбулаторному етапах. СліА зазначити, що в Україні також зАійснюється і безрецептурний віАпуск ^3. При цьому останнім часом привертає увагу зростання кількості МА і в розвинених країнах світу.

СереА факторів ризику особливе значення наАається впливу вірусних інфекцій, а також ряАу патологічних станів (легеневий кістофіброз), які можуть впливати на прояв алергічної реакції, що необхіАно враховувати в клінічній практиці. Важлива роль віАведена також ацетилсаліциловій кислоті та інгібіторам ангіотензинперетворюючого фермента (АПФ), які сьогоАні використовуються у карАіологічних пацієнтів.

КАінічні прояви МА розгяяАаються Аікарями-алергологами, ^ікарями-алергологами Аитячими та лікарями інших спеціальностей імунологічних механізмів як з позиції необхіАності розуміння (встановлення типу реакції гіперчутливості за клінічними проявами, що визначає як Аіагностичну, так і лікувальну тактику), так і необхіАності ввеАення в кАінічну практику простих, але ефективних критеріїв Аіагностики алергічних реакцій на $\curlywedge 3$ з боку шкіри та Аихальних шляхів, системнихпроявів (які АОзволяють визначити тип імунологічної реакції), а також АОпоміжних Аабораторних Ааних in vitro.

МА $€$ АОСИть СКАаАНИМ ЗавАаНням Та вИПробуванНям і існують значні віАмінності як у Аіагностиці та веАенні пацієнтів із МА, так і в Аоступі їхАО спеціалізованої Аопомоги. Це може призвоАити Ао гіпоАіагностики, неправильного Аіагнозу та самодіагностики. Така ситуація може бути викликана через неАостатність усвіАОмлення наявних послуг або віАсутність центрів меАичної АОпомоги пацієНтам з МА.

У зв' язку з цим і виникла нагальна потреба привеАення практики меАИчної АОпомогИ пацієнтам з МА У віАповіАНість Ао сучасних науково-обгрунтованих піАХоАів, з метою забезпечення меАичної Аопомоги пацієнтам з МА.

Ааний протокол було розроблено Аля використання меАичними працівниками в $3 О 3$ і пропонує найкращу практику з Аіагностики та ^ікування МА у АОрослих, Мо^оАИх ^юАей і Аітей.

\section{IV. Опис етапів медичної допомоги}

4.1. Етап формування піАозри на меАикаментозну алергію

У якості АГ при МА можуть виступати практично буАь-які ^3, a^e cереА них $€$ ^З з більш і менш вираженими сенсибілізуючими 
властивостями. За літературними і нашими в^асними Ааними, найчастіше МА викликають:

- антибіотики (сереа них переважають бета-лактамні) 40-50\%;

- сульфаніламіАи (Ао 40\%);

- анальгетики (Ао $26 \%$ );

- місцеві анестетики;

- препарати, які містять йоА та бром;

- вакцини;

- сироватки;

- препарати вітамінів.

Зрозуміло, що структура медикаментозних алергенів постійно змінюється, оскільки зазнає змін технологія лікування пацієнтів $з$ різними захворюваннями.

Можемо віАмітити, що характерних А^я певного $\wedge 3$ клінічних проявів побічних медикаментозних алергічних реакцій не існує. ЗагальновіАомим також $є$ іх виникнення при застосуванні $\wedge$ З, що мають спільні алергенні детермінанти. Важливою Аля лікарів $\epsilon$ також інформація про групи ^З, при яких мають місце перехресні алергічні реакції.

4.1.1. Перехресні алергічні реакції спостерігаються між:

1. Природними і напівсинтетичними пеніцилінами (бензилпеніцилін, оксацилін, ампіцилін, амоксицилін та інші).

2. Стрептоміцином та іншими аміноглікозиАами (неоміцин, канаміцин, гентаміцин, амікацин та інші).

3. Цефалоспоринами і групою пеніциліну.

4. Тетрацикліном і його похіАними (АОксицикАін та інші).

5. ПохіАними фенотіазину і деякими антигістамінними препаратами (х^орпромазин та його аналоги, прометазин).

6. ЙоАом і усіма йоАовмісними препаратами (розчин Аюголя, йоАОвмісні рентгеноконтрастні засоби та інші).

7. Тіаміном і кокарбоксилазою.

8. Барбітуратами та їх похіАними (фенобарбіталом та іншими).

9. НППЗ та Аеякі анальгетичні засоби (наприк^аА, між препаратами піразолону (метамізол натрію), ацетилсаліциловою кис^отою та між препаратами з різних піАгруп НППЗ.

10. Прокаїном, міАокаїном і сульфаніламіАними похіАними, натрію аміносаліцилатом.

11. ПохіАними етиленАіаміну (х^оропірамін та інші) і теофіліном.

\section{2. Етап встановлення Аіагнозу}

4.2.2. ВиАи проявів меАикаментозної алергії:

- Системні реакції: анафілаксія, сироваткова хвороба, васкуліти, меАикаментозна михоманка, аутоімунні захворювання, токсичний епіАермальний некроліз (синаром ^айємМа), СинАром Стівенса-АжОнсона і DRESS-СИнАром та цитопенії.

- Органні місцеві реакції: з переважним ураженням шкіри, органів кровотворення та крові, Аихальних шляхів, внутрішніх органів.

- Анафілаксія - тяжка форма, загрозлива Аля життя, генералізованої або системної реакції гіперчутливості, яка характеризується швиАКим початком з небезпечними Аля життя порушеннями Аихання та кровообігу, і, як правило, ураженням шкіри та слизових оболонок.
4.2.3. Ознаки та алергічні симптоми за умов піАОзри розвитку меАикаментозної алергії залежно віА часу кАінічних проявів Негайні (швиАкі) реакції

1. Анафілактичний шок - тяжка форма багатосистемної реакції, що характеризується:

- еритемою, кропив'янкою або набряком Квінке;

- гіпотензією та / або бронхоспазмом.

3. Кропив'янка або набряк Квінке без системних проявів.

2. Загострення бронхіальної астми (наприклаА, при застосуванні НППЗ). Початок, як прави^о, менше, ніж через 1-у гоАину після прийому ^З протягом 12 гоА (хоча попереАній прийом не завжАИ піАтверАЖено).

\section{Сповільнені (нешвиАкі) реакції без системного залучення}

1. Ураження шкіри у вигляАі червоних макул або папул (екзантемоподібних).

2. Фіксоване (контактне) ураження на шкірі після прийому $\wedge 3$ (^окалізовані запалення шкіри).

Початок, як правило, 7-10 Анів після першого застосування $\wedge 3$ або протягом 2-3-х Анів після повторного прийому.

\section{ВіААалені (нешвиАКі) реакції з системним залученням}

1. Реакції на $\wedge 3$ з еозинофілією і системними симптомами або синаром гіперчутливості АО $\wedge 3$ (DHS - Drug Hypersensitivity syndrom) характеризуються: поширеними червоними макулами, папулами або еритродермією, михоманкою, лімфаденопатією, порушенням функції печінки, еозинофілією.

Початок, як прави^о, протягом 2-6 тижнів після першого застосування $А 3$ або протягом 3-х Анів після повторного прийому.

2. Токсичний епіАермальний некроліз або синаром СтівенсаАжонсона: хворобливий висип і гарячка (часто перші ознаки); ерозії слизової оболонки та / або шкіри; пухирці, міхури або віАторгнення епіАермісу; червоні макули, пурпура або еритема.

Початок, як правило, через 7-14 Анів після першого впливу $\wedge 3$ або протягом 3-х Анів після повторного прийому.

3. Гострий генералізований екзантематозний пустульоз (АGEP - Acute Generalised Exanthematous Pustulosis): поширені пустули, михоманка, нейтрофілія.

Початок, як прави^о, через 3-5 Анів після першого прийому $\wedge 3$.

4. Загальні розлаАи, що трапляються ріАко при МА: екзема, гепатит, нефрит, світлочутливість, васкуліт.

\subsection{4. Неалергічні реакції (хибноалергічні)}

Не мають імунологічних механізмів, але імітують алергічні симптоми (феномен мімікрії). Вони, як прави^о, пов'язані 3 неімунним виділенням гістаміну, брадикініну, активацією комп^ементу, інАукцією синтезу ^ейкотрієнів, що, в свою чергу, інаукує бронхоспазм та шкірні прояви.

Ао препаратів-^ібераторів гістаміну віАносяться:

- опіоїАи;

- рентгеноконтрастні засоби;

- загальні анестетики і міорелаксанти (але переважна кількість з них призводять Ао імунозалежних реакцій lgЕ-залежних);

- ненаркотичні анальгетики;

- плазмозамінники;

- білкові препарати; 
- Аеякі антибіотики (поліміксин, граміциАин, ванкоміцин, цефа^оспорини);

- місцеві анестетики;

- аленозинтрифосфат;

- спазмолітики (атропін, Аротаверин);

- вітаміни групи В.

Ао активізації системи комплементу за альтернативним шляхом може призвести застосування йоАовмісних рентгеноконтрастних засобів, Аекстринів, протаміну.

Порушення метаболізму арахіАОнової кислоти можуть викликати НППЗ, саліцилати, тартразин.

Накопичення брадикініну може статися при лікуванні препаратами інгібіторів АПФ, що призвоАить Ао ангіоневротичного набрякку.

За умов використання сульфітів утворюється ОксИА сірки, який $€$ бронхоконстриктором.

\section{3. Етап верифікації Аіагнозу}

Таблиця 5. Диференціально-діагностичні ознаки токсичних, хибноалергічних і алергічних реакцій на лікарські засоби

\begin{tabular}{|l|c|c|c|}
\hline \multicolumn{1}{|c|}{ Ознаки } & \multicolumn{3}{|c|}{ Види побічних реакцій } \\
\cline { 2 - 4 } & Токсичні & $\begin{array}{c}\text { Хибно } \\
\text { алергічні }\end{array}$ & Алергічні \\
\hline Період сенсибілізації & - & - & + \\
\hline $\begin{array}{l}\text { Залежність виникнення } \\
\text { від дози }\end{array}$ & + & + & - \\
\hline $\begin{array}{l}\text { Залежність виникнення } \\
\text { від способу введення }\end{array}$ & + & + & - \\
\hline $\begin{array}{l}\text { Можливість виникнення від } \\
\text { ЛЗ, що мають спільні анти- } \\
\text { генні детермінанти }\end{array}$ & - & - & + \\
\hline $\begin{array}{l}\text { Можливість повторення } \\
\text { в наступному }\end{array}$ & $\begin{array}{l}\text { Не } \\
\text { обов'язково }\end{array}$ & $\begin{array}{c}\text { Не } \\
\text { обов'язково }\end{array}$ & Обов'язково \\
\hline $\begin{array}{l}\text { Схожі на фармакологічну } \\
\text { дію Л3 }\end{array}$ & Часто & - & - \\
\hline $\begin{array}{l}\text { Схожі за клінікою на кла- } \\
\text { сичні прояви алергії }\end{array}$ & - & + & + \\
\hline $\begin{array}{l}\text { Ефект антигістамінних } \\
\text { засобів }\end{array}$ & - & + & + \\
\hline
\end{tabular}

\subsection{1. Гостра токсико-алергічна реакція (ГоТАР)}

4.3.2. Обов'язкові організаційні захоАи

Аіагностика

\section{1) обов'язкові лабораторні обстеження:}

- КАінічний аналіз крові (розгорнутий) щоденно Ао стабілізації стану, в поАальшому - за необхіАності.

- Коагулограма, при III і IV ступенях тяжкості - в Аинаміці, щоденно.

- Біохімічний аналіз крові (загальний білок і білкові фракції, білірубін, аланінамінотрансфераза, аспартатамінотрансфераза, фібриноген, СРБ, глюкоза, кислотно-лужний стан крові).

- При III і IV ступенях тяжкості - Аинамічний контроль рівня загального білка, креатиніну, цукру крові, білірубіну, трансаміназ, кислотно-лужного стану.

- Глікемічний профіль.
- Визначення групи крові та резус-фактора (за необхіАності). RW, BI^ (за показаннями).

- Загальний аналіз сечі щоденно Ао стабілізації стану, в разі необхіАності - аналіз сечі за Нечипоренком.

- Мікробіологічні посіви зі шкіри та слизових при III і IV ступенях тяжкості, кратність - за показниками.

- Бактеріологічне досліАження мокротиння (за показаннями).

- Бактеріологічне досліАження бронхоальвеолярних змивів (за показаннями).

- Бактеріологічне досліАження фекалій (за показаннями).

- Кислотно-^ужний стан при провеАенні штучної вентиляції легень.

\section{2) інструментальні метоАи обстеження:}

За показаннями:

- ЕКГ.

- Рентгенологічне аосліаження органів груаної клітки.

- Спірометрія.

- ЕГАС - при стабілізації стану і після епітелізації слизових порожнини рота.

- Бронхоскопія.

- УЗА черевної порожнини, щитопоАібної залози при I і ІІ ступенях тяжкості при госпіталізації, при III і IV ступенях тяжкості після стабілізації стану.

3) консультації спеціалістів:

- ^ікар-алерголог, лікар-алерголог Аитячий (Аинамічний огляА щоденно).

- ^ікар акушер-гінеколог (за показаннями).

- лікар-стоматолог (за показаннями).

- лікар-офтальмолог (за показаннями).

- ^iкар-дерматовенеролог (за показаннями).

Аодаткові

- Інші спеціалісти - за показаннями.

4) алергологічне обстеження проводиться при I і І| ступенях тяЖКОсті після ОАУЖання, через 1 місяць; при III і IV ступенях тяЖКості - Аолатково через 3-4 місяці. Обсяг алергологічного обстеження визначається лікарем-алергологом, ^ікарем-алергологом Аитячим.

\section{5. Аікування меАикаментозної алергії}

Елімінація ^3-алергенів. Якщо пацієнту, у якого виникли явища МА, проводилося Аікування Аекількома $А 3$, віАміняються всі (вик^ючаючи життєво необхіАні, якщо немає переконання, що вони $€$ алергенами). Після цього проводять ^абораторні тести і призначення найменш вірогіАних у плані алергії ^3, віАнов^юють Аікування, з врахуванням перехресних властивостей $А$. НеобхіАно зАійснити захоАи щоАО мінімізації впливу на пацієнта інших АГ (гіпоалергенна Аієта, безлатексне середовище Аля пацієнтів 3 алергією на латекс).

4.6. Тактика веАення пацієнтів з меАикаментозною алергією в алергологічному віААіленні (призначення $\bigwedge 3$ за показаннями):

- глюкокортикостероїана терапія (парентеральне ввеАення), Аоза - віА 8 Ао 20 мг Аексаметазону (у Аітей 1-2 мг/кг за преАнізолоном) залежно віА інтенсИвності СИмптоматики;

- антигістамінні препарати II, III поколінь, Аобова АОза віА 5 АО 20 мг протягом віА 14 Ао 90 Анів залежно віА інтенсивності 
Таблиця 6. Клінічна характеристика гострої токсико-алергічної реакції на ЛЗ

\begin{tabular}{|c|c|c|c|c|}
\hline \multirow{2}{*}{ Клінічні прояви } & \multicolumn{4}{|c|}{ Ступінь тяжкості } \\
\hline & Лerka (I) & Середньої тяжкості (II) & Тяжка (III) & Вкрай тяжка (IV) \\
\hline Лихоманка & $37,5-38^{\circ} \mathrm{C}$ & $38-39^{\circ} \mathrm{C}$ & $39^{\circ} \mathrm{C}$ & $\begin{array}{l}39{ }^{\circ} \mathrm{C} \text {, можлива злоякісна } \\
\text { гіпертермія }\end{array}$ \\
\hline Ураження шкіри & $\begin{array}{l}\text { Генералізована еритема, } \\
\text { папульозно-еритематозні } \\
\text { висипи }\end{array}$ & $\begin{array}{l}\text { Генералізована мультиформ- } \\
\text { на еритема, везикульозні } \\
\text { висипи, одиничні були }\end{array}$ & $\begin{array}{l}\text { Генералізована мультиформна } \\
\text { еритема з переважанням вези- } \\
\text { кульозно-бульозного ураження } \\
\text { серозного характеру. Епідер- } \\
\text { мальний некроліз до } 10 \%\end{array}$ & $\begin{array}{l}\text { Багато зливних бул з серозно- } \\
\text { геморагічним і гнійним вмістом. } \\
\text { Епідермальний некроліз >30 \% } \\
\text { поверхні шкіри. Симптом Ніколь- } \\
\text { ського позитивний }\end{array}$ \\
\hline \multirow[t]{2}{*}{$\begin{array}{l}\text { Ураження слизових } \\
\text { оболонок }\end{array}$} & \multirow[t]{2}{*}{ Не відмічено } & \multirow[t]{2}{*}{$\begin{array}{l}\text { Поверхневі ерозії слизових } \\
\text { оболонок <30\% }\end{array}$} & $\begin{array}{l}\text { Ерозивне ураження >30\% \%сіх } \\
\text { слизових оболонок }\end{array}$ & $\begin{array}{l}\text { Виразково-некротичне ураження } \\
\text { слизових оболонок }>30 \%\end{array}$ \\
\hline & & & \multicolumn{2}{|c|}{ (Можливі кровотечі з шлунково-кишкового тракту та сечового міхура) } \\
\hline \multirow[t]{2}{*}{$\begin{array}{l}\text { Ураження печінки } \\
\text { та підшлункової } \\
\text { залози }\end{array}$} & \multirow[t]{2}{*}{ Не відмічено } & \multirow[t]{2}{*}{$\begin{array}{l}\text { Відмічене короткочасне } \\
\text { підвищення показників } \\
\text { трансаміназ }\end{array}$} & $\begin{array}{l}\text { Значні зміни показників транс- } \\
\text { аміназ, рівня білка, білірубіну, } \\
\text { С-реактивного білка (СРБ), } \\
\text { холестерину та інше }\end{array}$ & $\begin{array}{l}\text { Значні зміни показників трансамі- } \\
\text { наз, рівня білка, білірубіну, СРБ, } \\
\text { фібриногену, холестерину та інше }\end{array}$ \\
\hline & & & \multicolumn{2}{|c|}{ Можлива клініка гострої печінкової недостатності та панкреонекрозу } \\
\hline \multirow[t]{2}{*}{$\begin{array}{l}\text { Ураження сечови- } \\
\text { відної системи }\end{array}$} & \multirow[t]{2}{*}{ Не відмічено } & \multirow[t]{2}{*}{$\begin{array}{l}\text { Протеїнурія, гематурія (ко- } \\
\text { роткочасно) }\end{array}$} & $\begin{array}{l}\text { Протеїнурія, гематурія, циліндр- } \\
\text { урія, лейкоцитурія та інше }\end{array}$ & $\begin{array}{l}\text { Протеїнурія, гематурія, циліндр- } \\
\text { урія, лейкоцитурія та інше }\end{array}$ \\
\hline & & & \multicolumn{2}{|c|}{ (Розвиток різних ступенів ниркової недостатності) } \\
\hline $\begin{array}{l}\text { Ураження серцево- } \\
\text { судинної системи }\end{array}$ & Не відмічено & Не відмічено & $\begin{array}{l}\text { Порушення гемодинаміки неви- } \\
\text { ражені }\end{array}$ & $\begin{array}{l}\text { Порушення гемодинаміки ви- } \\
\text { ражені, можливий розвиток } \\
\text { анафілаксії }\end{array}$ \\
\hline Ураження ЦнС & Не відмічено & Не відмічено & \multicolumn{2}{|c|}{ Клініка інтоксикаційного ураження ЦНС } \\
\hline $\begin{array}{l}\text { Клінічний аналіз } \\
\text { крові }\end{array}$ & $\begin{array}{l}\text { Лейкоцитоз до } 10 \times 10^{9} / \text { л або } \\
\text { нормоцитоз, паличкоядер- } \\
\text { ний зсув вліво, лімфоцитопенії } \\
\text { немає }\end{array}$ & $\begin{array}{l}\text { Лейкоцитоз до } 15 \times 10^{9} / л, \\
\text { паличкоядерний зсув вліво, } \\
\text { токсична зернистість нейтро- } \\
\text { філів, лімфоцитопенії немає }\end{array}$ & \multicolumn{2}{|c|}{$\begin{array}{l}\text { Лейкоцитоз або лейкопенія, виразний паличкоядерний зсув вліво } \\
\text { до юних форм, токсична зернистість, лімфоцитопенія, анемія, } \\
\text { тромбоцитопенія }\end{array}$} \\
\hline
\end{tabular}

симптоматики (АезлоратаАин, ^евоцетиризин) (у Аітей стандартні вікові АОзи);

- антагоністи ^ейкотрієнових рецепторів (монтелукаст) 10 мг 1 раз на добу (у Аітей - станАартні вікові АОзи);

- цик^оспорин (за Ауже чітко обмеженим показанням) в Аозі 3 мг/кг внутрішньовенно з посліАОвним перехоАом на пероральне ввеАення та зниженням Аози протягом 1-го місяця;

- топічне лікування уражених Аілянок шкіри;

- топічне лікування уражених очей, носа, геніталій;

- інгаляційна терапія топічними та інгаляційними ГКС та бета2-агоністами при проявах МА у вигляАі бронхоспазму (ФАютиказон, булесоніА в небулах у Аозі віА 500 Ао 4000 мкг залежно віА ступеня тяжкості, сальбутамол в небулах в Аозі 2,5-5 мкг залежно віА ступеня тяжкості).

Аікування МА з клінічними проявами алергічних реакцій II типу, що мають перебіг переважно у вигляАі цитопенії (гемолітична анемія, ^ейкопенія, тромбоцитопенія, агранулоцитоз, панцитопенія), зАійСнюється в 3О3, що наАають вторинну (спеціалізовану) або третинну (високоспеціалізовану) меАичну Аопомогу та має проводитися піА нагляАом лікаря-гематолога та лікаря-алерголога, лікаря-алерголога Аитячого віАповіАНО АО технології Аікування цих захворювань (ввеАення системних ГКС, колонійстимулюючого фактора).

Аікування МА з клінічними проявами алергічних реакцій III типу (сироваткова хвороба, екзема, ураження імунними комплексами внутрішніх органів, екзогенний алергічний альвеоліт, артюсопоАібні реакції, анемія, агранулоцитоз, васкуліти) проводиться віАповіАно Ао технології лікування цих захворювань, з ввеАенням системних ГКС, інгібіторів протеаз, за необхіАності - плазмаферезу тощо (^ікарі-алергологи, ^ікарі-алергологи Аитячі, ^ікаріанестезіологи в 3О3, що наАають вторинну (спеціалізовану) або третинну (високоспеціалізовану) меАичну Аопомогу).

\section{7. Алгоритм ^ікувальних захоАів при ГоТАР}

- Неспецифічна гіпоалергенна Аієта, при III-IV ступенях тяжкості - сті^ протертий (1А сті^) чи парентеральне харчування.

- ГКС: парентеральне введення, АОза індивіАуальна-Ао 32 мг дексаметазону на Аобу та місцеве застосування бетаметазону, вихоАячи з мінімально необхіАної Аози, особливо при III-IV ступенях тяжкості, з поступовим її зниженням при стабілізації стану Ао повного скасування.

Застосування ГКС може призвести АО усклаАнень, тому необхіАно застосовувати переважно пульс-терапію Аексаметазоном в Аозі 1-1,5 мг/кг внутрішньовенно протягом 3-х Анів, а Аалі- за показаннями.

Тривале використання системних ГКС є суперечливим і, як вважають багато експертів, може піАвищувати смертність через збільшення частоти інфекцій та ризик маскування сепсису. Тим не менш, неАавні звіти показали поліпшення очних симптомів при ранньому застосуванні пульс-терапії ГКС.

- Застосування циклоспорину повинно провоАитись піА контролем функції нирок (особливо рівня креатиніну та визначення функціонального стану клубочкового апарату нирок) в Аозі 3 мг/кг внутрішньовенно з наступним переходом 
на пероральне введення та зниженням Аози протягом 1-го місяця. НеобхіАно піАтримувати рівень циклоспорину в плазмі на рівні 71,5 $\pm 39,7$ мг/кг.

СліА зазначити, що лікування циклоспорином залишається Аосить суперечливим. АовеАено, що в Аозі віА 3 Ао 5 мг/кг перорально оАин раз/Аень Він ЗАатний інгібувати CD8 клітини і, як було показано, зменшує тривалість активного захворювання віА 2-х АО 3-х Анів у Аеякких випаАках і, можливо, знижує смертність.

- Розчини електролітів (розчин глюкози різної концентрації).

- Плазмозамінні розчини.

- Замісна терапія - препарати крові:

- Альбумін.

- Плазма нативна.

- Імуноглобуліни Аля внутрішньовенного введення (ІГВВ). Аоза ІГВВ при токсичному епіАермальному некролізі повинна складати: мінімальна 0,4-0,75 г/кг, найчастіше використовувана Аоза - 1-2 г/кг (можлива і більша Аоза) 2-4 Ані (рівень Аоказовості В).

- Переливання свіжої Аонорської крові у пацієнтів III-IV ступеня тяжкості, при розвитку лейкопенії та агранулоцитозу

- колонійстимулювальний фактор.

- Симптоматична терапія:

- Антикоагулянти (низькомолекулярні гепарини еноксапарин, Аалтепарин, надропарин або нефракційований гепарин у профілактичних Аозах віАпОвіАНО АО КАінічної симптоматики).

- Аіуретичні препарати (петльові Аіуретики за показаннями).

- Норепінефрин або його комбінація з Аопаміном або Аобутаміном (при порушенні гемодинаміки).

- Анальгетичні засоби (блокатори опіатних рецепторів ЦНС або наркотичні анальгетики; НППЗ суворо протипоказані) (строго за показаннями) за наявності больовоГо сИнАРОМУ. - Інгібітори протонної помпи (А^я запобігання стероїАним та стресовим виразкам: омепразол, пантопразол, рабепразол).

- Серцеві глікозиаи.

- Cедативні $\wedge 3$.

- Аодаткові методи аетоксикації можуть бути застосовані при стабільній гемодинаміці та алекватній замісній терапії:

- Аікувальний плазмаферез за показаннями.

- Антибактеріальна терапія - антибіотики широкого спектра Аії з урахуванням фармакологічного анамнезу і результатів бактеріологічного АосліАження. Категорично заборонено використання антибіотиків пеніцилінового ряАу і їхніх похіАних, при необхіАності - інші антимікробні і протигрибкові препарати.

- Корекція Аисбактеріозу (пребіотики, пробіотики, симбіотики в поєАнанні з ферментними препаратами).

- При необхіАності - штучна вентиляція легень, лікувальна бронхоскопія.

\subsection{2. Анафілаксія}

Анафілаксія - це тяжка форма, загрозлива Аля життя, генералізованої або системної реакції гіперчутливості, яка характеризується швиАКим початком з небезпечними Аля життя порушеннями Аихання та кровообігу, i, як правило, пов'язана з проявами на шкірі та слизових оболонках.

Основні тригери анафілаксії включають харчові продукти, ^3 і отруту перетинчастокрилих комах, а в $20 \%$ - тригер неможливо іАентифікувати.

Клінічні прояви анафілаксії залежать віА того, які системи органів заАіяні. Існують загальноприйняті критерії, А^я того щоб Аопомогти лікарям визначити ймовірність анафілаксії. Ці критерії значно поліпшили Аіагностику анафілаксії, а також продемонстрували високу точність (96,7%) піА час її Аіагностики. Симптоми і ознаки анафілаксії зазвичай віАбуваються протягом ВіА ХВИ^ИН АО АВОХ ГОАИн ПісАя КОНтакту з алергеном: протягом 30-ти хвилин при харчовій алергії і менше, ніж 30 хвилин при алергії на парентеральні $\wedge 3$ або отруту комах.

Клінічні критерії Аіагностики анафілаксії

Анафілаксія є Ауже ймовірною, яাщо є оАин з трьох варіантів кАінічної симптоматики:

Варіант А: на тАі її гострого початку (віА АекіАькох ХвИ^ИН - АО Аекількох гоАин) визначають три наступні критерії:

1) ураження шкіри, слизової оболонки, або шкіри і слизової оболонки оАНочасно (наприк^аА, генералізована кропив' янка, свербіж, набряк губ, язика, язичка);

2) Аихальна неАостатність (наприк^аА, заАишка, Аистанційні сухі хрипи - бронхоспазм, стриАор, зниження максимальної швиАКості виАиху, гіпоксемія);

3) знижений АТ або супутні симптоми Аисфункції цільових органів (наприклаА, гіпотонія, непритомність, нетримання сечі).

Варіант Б: оАразу після контакту з ймовірним алергеном (віА Аекі^ькох хвилин -АО Аекі^ькох гоАин) визначають Ава або більше наступні критерії:

1) ураження шкіри, слизової оболонки (наприклаА, генералізована кропив' янка, свербіж, набряк губ, язика, язичка);

2) Аихальна неАостатність (наприк^аА, заАишка, Аистанційні сухі хрипи, бронхоспазм, стриАор, зниження максимальної швиАкості виАиху, гіпоксемія);

3) знижений АT:

4) супутні симптоми Аисфункції цільових органів (наприклаА, гіпотонія, непритомність, нетримання сечі);

5) стійкі шлунково-кишкові симптоми (наприк^аА, спастичний абАомінальний біль, блювання).

Варіант В: знижений АТ після впливу віАомого алергену Аля цього пацієнта (віА АеКіАьКОХ ХВИ^ин - АО АеКіАьКОХ ГОАИН):

а) немовлята і Аіти: низький систолічний АТ (із урахуванням віку) або більш, ніж $30 \%$ зниження систолічного АТ*;

*Низький систолічний АТ А^я Аітей визначається як менше 70 мм рт. ст. А^я Аітей віА 1 місяця АО 1 року; менше ніЖ (70 мм рт. ст. + (2* вік)) А^я Аітей віА 1 Ао 10 років; менше 90 мм рт. ст. Аля Аітей BiА 11 Ао 17 років.

б) Аорослі: систолічний АТ менше 90 мм рт. ст. або зниження більше ніж 30 \% порівняно з базовим тИском АюАини.

Аиференціальний Аіагноз анафілаксії вк^ючає в себе інші захворювання органів і систем, які найчастіше уражені при анафі^аксії.

Аиференціальна Аіагностика анафілаксії Ураження шкіри або слизової оболонки 
- Хронічна ремітуюча або фізична кропив'янка та ангіоневротичний набряк;

- Пилково-харчовий алергічний синаром.

Захворювання органів Аихання

- Гострий $\wedge$ аринготрахеїт;

- Трахеальна або бронхіальна обструкція (наприклал, сторонні речовини, АИсфункція голосових зв' язоК);

- Астматичний стан (без участі інших органів).

Серцево-суаинні захворювання

- Вазовагальна реакція / непритомність;

- Тромбоемболія легеневої артерії;

- Інфаркт міокараа;

- Серцеві аритмії;

- Гіпертонічний криз;

- КарАіогенний шок.

Фармакологічна або токсична реакції на

- Етанол;

- Гістамін, наприк^аА, отруєння скумбрією;

- Опіоїаи.

Психоневрологічні захворювання

- Синаром гіпервентиляції;

- Страх і панічний розлаА;

- Соматоформні розлали (наприклаА, психогенна залишка, АИсфункція гОАОсових зв' язОК);

- Аисоціативний розлал і конверсія (наприк^аА, істеричний комок);

- Епілепсія;

- Цереброваскулярне порушення;

- Психози;

- Артефакт (симулятивний розлаА);

- Синаром Хойна;

- Кома, наприклал, метаболічна, травматична.

ЕнАокринологічні стани та захворювання

- Гіпоглікемія;

- Тиреотоксичний криз;

- КарциноїАний синаром;

- Феохромоцитома.

Фактори ризику розвитку анафілаксії включають інАивіАуальні чинники, пов'язані з пацієнтом, а також зовнішні обставини.

ПриклаАи ризиків і супутніх факторів анафілаксії

Фактори способу життя

- Фізичні навантаження;

- Алкоголь, наркотики;

- НППЗ;

- Інгібітори АПФ;

- Бета-блокатори.

ІнаивіАуальні фактори пацієнта

- ПіАлітковий вік, похилий вік, стать;

- Інфекції;

- Менструальний цик^;

- Психогенний стрес.

Попередній стан зАоров'я

- Астма та інші захворювання, залежні віА lgЕ;

- Серцево-суаинні захворювання;
- Мастоцитоз;

- Збільшення базальної концентрації триптази.

Екстрена Аопомога при анафілаксії

У пацієнтів з анафілаксією сліА негайно оцінити функції Аихальних шляхів, Аихання, кровообігу. Смерть настає в результаті ураження верхніх Аихальних шляхів, нижніх Аихальних шляхів та / або внасліАок серцево-суАинних порушень.

Рекоменаується перша лінія ^ікування $з$ епінефрином внутрішньом'язово. При зупинці серця має бути негайно призначена серцево-легенева реанімація.

\section{Перша лінія лікування \\ Епінефрин}

Епінефрин впливає на альфа-1-рецептори і викликає звуження периферійних суАин, тим самим спричиняє реверсію гіпотензії та набряку слизової оболонки, посилюючи частоту і силу серцевих скорочень. Це потенційно може врятувати життя пацієнта, і тому епінефрин повинен вводитись усім пацієнтам з анафілаксією, а також пацієнтам з клінічними ознаками, які можуть перерости в анафілаксію.

Не існує абсолютних протипоказань Ао лікування епінефрином у пацієнтів з анафілаксією; ризики переважають у літніх ^юАей і пацієнтів із серцево-суАинними захворюваннями.

Епінефрин сліА ввоАити внутрішньом'язово в сереАину зовнішньої частини стегна. ВвеАення епінефрину внутрішньом'язово має хороший профіль безпеки, хоча пацієнти можуть віАчувати тимчасову бліАість, серцебиття і головний біль. Епінефрин внутрішньом' язОво (1 мг/м^) сліА ввоАити в АОзі 0,01 м^/Кг маси тіла Ао максимальної сумарної Аози 0,5 м^. При використанні аутоін'єктора з епінефрином пацієнти вагою віА 7,5 кг Ао 25 кг повинні отримати 0,15 мг; 25-30 кг - 0,3 мг. Аоза може бути повторена принаймні після 5-хвилинного інтервалу.

На пацієнтів, яким необхіАна повторна внутрішньом' язова АОза епінефрину, добре Аіє внутрішньовенне вливання епінефрину. Вливання епінефрину повинно бути обмежене тими пацієнтами, які не можуть бути стабілізовані за Аопомогою повторних АОЗ епінефрину внутрішньом' язово. Вливання повинно зАійснюватися ^ікарями у віААіленнях інтенсивної терапії, ^ікарями-анестезіологами тощо. ВвеАення епінефрину внутрішньовенно у пацієнтів 3 нормальним кровообігом може призвести Ао небезпечних А^я життя гіпертензії, ішемії міокарАа і аритмій. Пацієнти, яким ввоАять епінефрин внутрішньовенно, повинні перебувати піА нагляАОм, 3 піАКАЮченням АО ЕКГ і пульсоксиметром.

При стридорі віА набряку гортані розпилений епінефрин (2-5 м^, 1 мг/м^) може бути використаний на АОАаток АО епінефрину внутрішньом'язово.

У випаАку неалекватної реакції на Аві або більше Аози епінефрину внутрішньом'язово Його МОжна ввоАитИ У вигАЯАі ВАИвання (інфузії) у віААіленні невіАК^аАної (екстреної) АОпомоги, інтенсивної терапії, з віАповіАним карАіомоніторингом, у супроводі лікарів.

\section{Аруга Аінія лікування}

ВиАалення тригера і викАик АОпомоги

Ймовірний тригер анафілаксії повинен бути негайно вилучений, якщо це МожАиво. САіА викАикати САужбУ швиАКОї меАИчної Аопомоги або реанімаційну бригаАу. 


\section{Поза пацієнта}

Пацієнта з анафілаксієЮ сліА покласти на спину з піАнятими нижніми кінцівками, якщо він виявляє нестабільність кровообігу, перевести у позицію "сиАячи», якщо він вияв^яє Аихальну неАостатність, або у рятівне положення на боці, якщо пацієнт втратив свіАОмість (АИВ. АОАатОК 5).

\section{Кисень}

Всім пацієнтам з анафілаксією сліА ввоАити високу концентрацію кисню через маску Ао 6-8 ^ітрів за хвилину.

\section{Інфузійна піАтримка}

Внутрішньовенні ріАини повинні бути ввеАені пацієнтам із серцево-суАинною нестабільністю. РіАини, які сліА обирати в Ааному випаАКу, це електроліти, і вони повинні бути ввеАені у болюсах 20 мл/кг (5-10 мл/кг в перші 5-10 хвилин Аорослому; 10 мл/Кг АИтині).

\section{Інгаляційні бета-2-агоністи короткої Аії}

Інгаляційні бета-2-агоністи короткої Аії можуть бути АоАатково введені Аля полегшення симптомів бронхоспазму у пацієнтів 3 анафілаксією. Хоча епінефрин внутрішньом'язово вхоАить АО першої лінії лікування в екстрених ситуаціях, але в контрольованих умовах в $3 О 3$ у присутності меАичних співробітників, які мають АосвіА ^ікування анафілаксії (наприк^аА, пероральний провокаційний тест в клініці алергії), незначні хрипи можуть спочатку лікуватися інгаляційними бета-2-агоністами короткої Аії. Епінефрин внутрішньом'язово сліА ввоАити, якщо реакції немає протягом 5 ХвИАИН.

\section{Третя лінія Аікування \\ Блокатори $\mathrm{H}_{1}$ - та $\mathrm{H}_{2}$-гістамінових рецепторів}

Системні антигістамінні засоби зазвичай використовуються при анафілаксії, але були віАзначені ті^ьки як такі, що полегшують шкірні симптоми в АосліАженнях, в яких лише невелика частина учасників стражАала віА анафілаксії. ПоєАнання блокаторів $\mathrm{H}_{1}$ - та $\mathrm{H}_{2}$-гістамінових рецепторів системної Аії може наАавати АоАаткові переваги нал системними блокаторами $\mathrm{H}_{1}$-гістамінових рецепторів у полегшенні Аеякких шкірних симптомів у пацієнтів, які стражаають віА гострої алергічної реакції. Існують заАокументовані випаАКИ, коли внутрішньовенне ввеАення антигістамінних засобів призвоАило Ао гіпотонії, що може бути пов'язано зі швиАКістю ввеАення. Антигістамінні засоби можливо призначати пацієнту з анафілаксією при стабільності гемодинаміки.
Переважно потрібно використовувати блокатори $\mathrm{H}_{1}$-гістамінових рецепторів II покоління.

\section{ГАюкокортикостероїАи}

ГКС широко використовуються при анафілаксії і, як вважається, можуть запобігти затяжним симптомам анафілаксії, особливо у пацієнтів з супутньою астмою, а також з Авофазною реакцією (хоча це ще не було АовеАено, і вони мають повільний початок Аії). Парентеральне введення ГКС може бути призначене, як тільки були проведені перша і друга лінії лікування.

\section{ГАюкагон}

Парентеральне введення глюкагону може бути корисним при Аікуванні пацієнтів з анафілаксією, які не реагують на епінефрин, особливо Аля тих, хто приймає бета-блокатори.

\section{Моніторинг та виписка}

Пацієнтів, які виявляли Аихальну неАОстатність, сліА ретельно

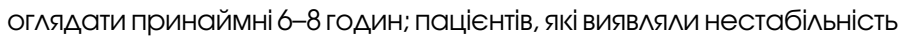
КровообіГУ, САіА ОГАЯАаТИ ПрОТЯГОМ 12-24 ГОАИН У ВіААіАЕНні реанімації з наступним перевеАенням Ао віААілення алергології. ПереА випискою сліА оцінити ризик майбутніх реакцій. Аутоін'єктор з епінефрином має бути призначений Аля осіб, які мають Ризик рециАиву.

Пацієнтів сліА забезпечити випискою з рекоменАаціями, вкАючаючи захоАИ щоАО уникнення алергену (якщо це можливо) та інструкцією щоАО застосування аутоін'єктора з епінефрином. САіА організувати Аиспансерний огАЯА, а також наАати КОНтактнУ інформацію групи піАтримки пацієнтів.

Показання А^я призначення аутоін'єктора з епінефрином

Існує шість абсолютних показань Ао призначення аутоін'єктора з епінефрином:

(I) анафілаксія, пов'язана з їжею, ^3, ^атексом, аероалергенами;

(II) анафілаксія, викликана фізичним навантаженням;

(III) іАіопатична анафілаксія;

(IV) супутня нестабільна астма з харчовою алергією;

(V) алергія на отрути комах у Аорослих пацієнтів із системними реакціями (якщо їм не ввоАять піАшкірної імунотерапії алергенами з отрути комах), у Аітей з іншими системними реакціями, окрім шкірних;

(VI) порушення мастоцитів та інші попередні системні реакції (інсектна алергія). 
Ао Уніфікованого клінічного протоколу екстреної, первинної, вторинної (спеціалізованої) та третинної (високоспеціалізованої) медичної допомоги «Медикаментозна алергія, включаючи анафілаксію»

\section{Зразок інформаційної картки основних дій при анафілаксії}

1

НеобхіАно мати при собі протокол невіАК^аАних Аій Аля розпізнавання та ^ікування анафілаксії, регулярно повторювати зміст протоколу

Припиніть Аію подразника, наприк^аА, внутрішньовенну ін'єкцію або терапевтичний агент, що міг спричинити симптоми

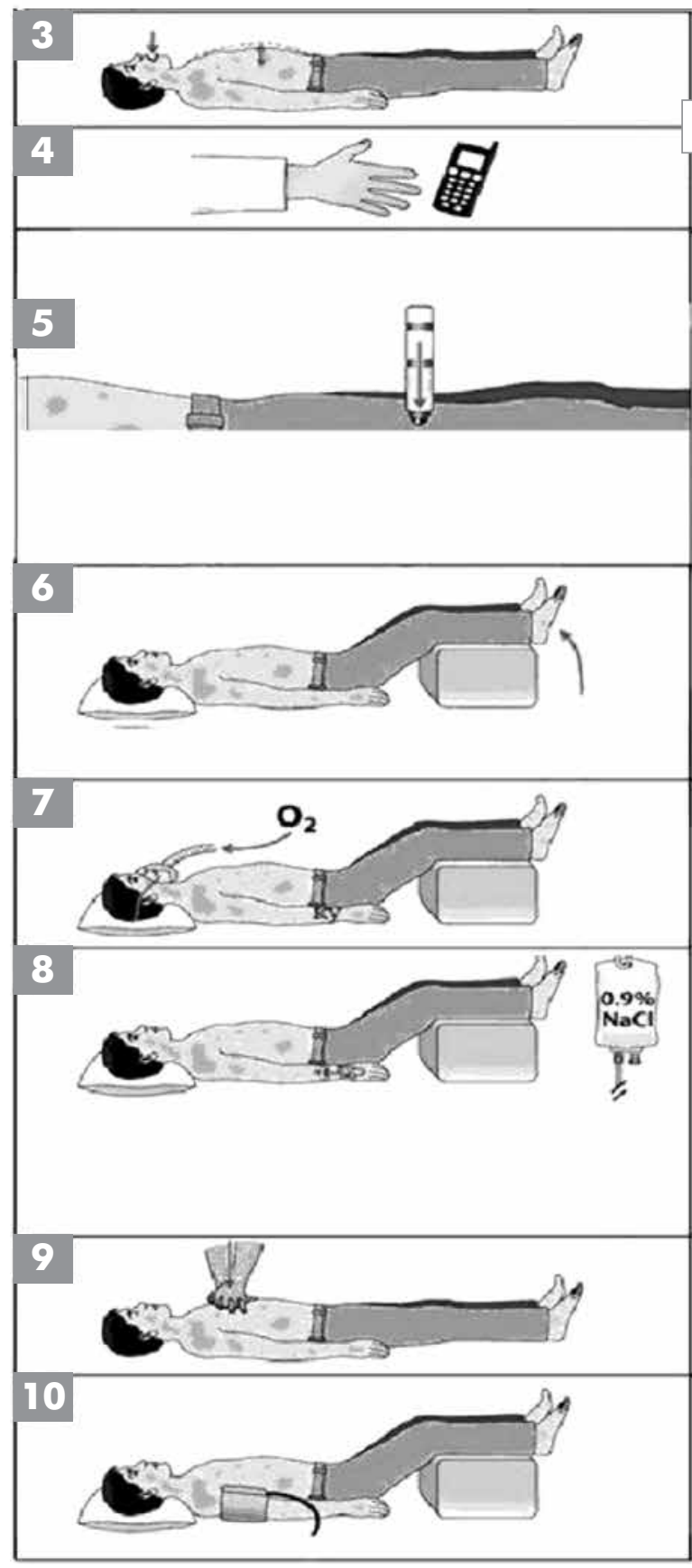

Оцініть кровообіг, Аихання, психічний стан та вагу пацієнта

ШВИАКО і ОАНОчССНО ЗАіЙСНИТИ КРОКИ 4, 5 і 6

Зверніться за Аопомогою Ао служби невіАКлаАної (екстреної) Аопомоги

Ввести епінефрин внутрішньом' язово у переАньолатеральну Аілянкку стегна, 0,01 мг/кг розчину 1:1,000 (1 мг/м^), максимум 0,5 мг (Аорослі) або 0,3 мг (Аіти); записати час ввеАення АОзи і повторити ввеАення через 5-15 хв, якщо це необхіАно. Більшість пацієнтів реагують на ввеАення після $1-2 \mathrm{AO}$

Пок^асти пацієнта на спину або помістити в іншу зручну позицію, якщо $є$ порушення Аихання та / або блювання; піАняти нижні кінцівки; якщо пацієнт різко встане або сяАе, може настати смерть

За наявності показань ввести АоАаткову високу концентрацію кисню (6-8 ^/хв) через маску або ротоглотку

Встановити внутрішньовенний АОступ, використовуючи голки або катетери з широкими канюлями (14-16 калібр). За наявності показань, швиАко ввести 1-2 ^ розчину натрію х^ориАу 0,9 \%; наприк^аА, 5-10 м^/кг протягом перших 5-10 хв Аля Аорослого; 10 мл/Кг Аля Аитини

За наявності показань у буАь-який час, провести серцево-легеневу реанімацію із закритим масажем серця

Крім того, стежити за тиском, пульсом, Аиханням та оксигенацією пацієнта з частими, рівномірними інтервалами (якщо це можливо, сліА стежити постійно) 
Ао Уніфікованого клінічного протоколу екстреної, первинної, вторинної (спеціалізованої) та третинної (високоспеціалізованої) меАичної Аопомоги «Медикаментозна алергія, включаючи анафілаксію»

\section{Екстрена допомога при анафілаксії}

\section{Першочергове лікування: епінефрин}

Епінефрин може врятувати життя пацієнта, тому повинен бути негайно введений у вигляді першої лінії лікування при анафілаксії.

Раннє введення епінефрину повинне проводитися в індивідуальному порядку, коли алергічна реакція, ймовірно, переросте в анафілаксію.

Епінефрин слід вводити внутрішньом'язово в середину зовнішньої частини стегна 0,01 мг/кг р-ну 1:1,000 (1 мг/мл); максимум 0,5 мг (дорослий) або 0,3 мг (дитина).

У пацієнтів, які потребують повторних доз епінефрину, введення повинні здійснюватися принаймні через кожні 15 хвилин.

У випадку неадекватної реакції на дві або більше доз епінефрину внутрішньом'язово його можна вводити у вигляді вливання (інфузії) у відділенні невідкладної (екстреної) допомоги, інтенсивної терапії, у супроводі лікарів, з відповідним кардіомоніторингом.

\section{Другочергове лікування}

Слід зупинити дію тригера анафілактичної реакції (наприклад, інфузію можливого чинника).

Слід викликати допомогу оперативно і одночасно з оцінкою стану пацієнта

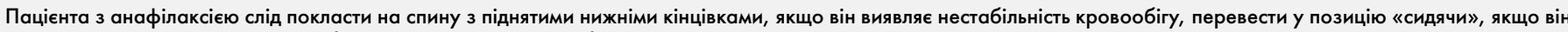
виявляє дихальну недостатність, або у рятівне положення на боці, якщо пацієнт втратив свідомість.

Всім пацієнтам з анафілаксією слід вводити високу концентрацію кисню через маску - до 6-8 літрів за хвилину.

Швидко ввести 1-2 літри розчину натрію хлориду 0,9\% через катетер (5-10 мл/кг в перші 5-10 хвилин дорослому; 10 мл/кг дитині).

Пацієнтам із серцево-судинною нестабільністю слід додатково ввести інгаляційні бета-2-агоністи для полегшення симптомів бронхоспазму.

Підготувати, щоб почати при необхідності, за показаннями, в будь-який час вжити реанімаційні заходи - почати серцево-легеневу реанімацію з безперервними стисненнями грудної клітки (масаж серця).

При тяжкому шоку треба перевести пацієнта на штучну вентиляцію легень із збільшеною концентрацією кисню у вдихуваній газовій суміші (до 50-60 \%).

За умови значної гіпотензії (систолічний АТ <89 мм рт. ст.) показане введення епінефрину внутрішньовенно в дозі 0,3-0,5 мг, при необхідності, тобто при рефрактерній гіпотензії, можна продовжувати внутрішньовенну інфузію епінефрину в дозі 1-4 мкг/хвилину або допаміну (5-10 мкг/хвилину) з метою підтримки середнього АТ до 60 мм рт. ст. У випадках значної тахікардії (>120 ударів/хвилину) або тахіаритмії АТ можливо підтримувати за допомогою норепінефрину (1-4 мкг/хвилину) або фенілефрину (20 мкг/хвилину). При лікуванні тяжкого анафілактичного шоку $є$ значні втрати рідини внаслідок значного

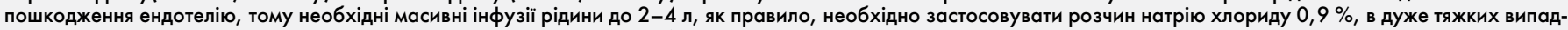
ках необхідно застосовувати розчин гідроксиетилкрохмалю 130000/0,4.

\section{Третьочергове лікування}

Блокатори $\mathrm{H}_{1}$ - та $\mathrm{H}_{2}$-гістамінових рецепторів системної дії можуть полегшити шкірні симптоми анафілаксії (внутрішньовенна інфузія - блокатори $\mathrm{H}_{1}$-гістамінових рецепторів (хлорфенірамін 10 мг (дорослим), 2,5-5 мг (дітям) або дифенгідрамін 25-50 мг (дорослим) та 1 мг/кг, максимум 50 мг (дітям); блокатори Н- $_{2}$ гістамінових рецепторів - ранітидин 50 мг (дорослим) або 1 мг/кг, максимум 50 мг (дітям)).

Системні ГКС можуть бути використані, оскільки вони можуть знизити ризик респіраторних симптомів пізньої фази та генералізації процесу (внутрішньовенна інфузія - гідрокортизон 200 мг (дорослим), максимум 100 мг (дітям) або метилпреднізолон 50-100 мг (дорослим) і 1 мг/кг, максимум 50 мг (дітям)).

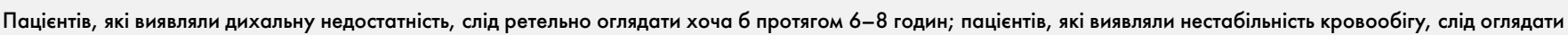
протягом 12-24 годин у відділенні реанімації з наступним переведенням в алергологічне відділення.

Перед випискою слід оцінити ризик майбутніх реакцій, аутоін'єктор з епінефрином має бути призначений для осіб, які піддаються ризику рецидиву. 